\title{
Effects of mealworm (Tenebrio molitor) larvae hydrolysate on nutrient ileal digestibility in growing pigs compared to those of defatted mealworm larvae meal, fermented poultry by-product, and hydrolyzed fish soluble
}

\author{
Kyung Hoon Cho ${ }^{1}$, Sun Woo Kang ${ }^{2}$, Jong Sang Yoo ${ }^{1}$, Dae Kil Song ${ }^{3}$, Yi Hyung Chung ${ }^{3}$, \\ Gyoo Taik Kwon ${ }^{4}$, and Yoo Yong Kim ${ }^{2, *}$
}

\footnotetext{
* Corresponding Author: Yoo Yong Kim Tel: +82-2-878-5838, Fax: +82-2-878-5839, E-mail: yooykim@snu.ac.kr

'Daehan feed Co., Ltd., R\&D Center, Incheon 22300, Korea

${ }^{2}$ Department of Agricultural Biotechnology, College of Animal Life Sciences, Seoul National University, Seoul 08826, Korea

${ }^{3}$ Jeonbuk Institute for Food-Bioindustry, Jeonju 54810, Korea

${ }^{4}$ Berry \& Biofood Research Institute, Gochang 56417, Korea
}

ORCID

Kyung Hoon Cho

https://orcid.org/0000-0001-5036-3553 Sun Woo Kang

https://orcid.org/0000-0003-0101-3682 Jong Sang Yoo

https://orcid.org/0000-0002-1995-9858 Dae Kil Song

https://orcid.org/0000-0002-2584-3704 Yi Hyung Chung

https://orcid.org/0000-0001-5470-8360

Gyoo Taik Kwon

https://orcid.org/0000-0001-8076-4059

Yoo Yong Kim

https://orcid.org/0000-0001-8121-3291

Submitted Oct 2, 2019; Revised Nov 25, 2019; Accepted Dec 23, 2019
Objective: To investigate effect of mealworm (Tenebrio molitor) larvae hydrolysate on nutrient ileal digestibility compared to those of dried mealworm larvae meal, fermented poultry by-product, and hydrolyzed fish soluble in growing pigs.

Methods: A total of 12 crossbred ([Landrace $\times$ Yorkshire $] \times$ Duroc) growing pigs with average body weight of $28.70 \pm 0.32 \mathrm{~kg}$ were surgically equipped with simple T-cannulas. A total of 12 pigs were assigned to individual metabolic crates and allotted to one of four treatments with 3 replicates in a fully randomized design.

Results: Apparent ileal digestibility (AID) of dry matter (DM) was the highest in pigs fed HML diet. AIDs of crude protein (CP) were higher in pigs fed HML and DMLM diets than those in pigs fed the other two diets. AID of total amino acid was higher $(\mathrm{p}=0.06)$ in pigs fed HML diet. AIDs of lysine (Lys), methionine (Met), and threonine (Thr) were similar in pigs fed DMLM and HML diets, but were higher $(p=0.05, p<0.05$, and $p=0.05$, respectively) than those in pigs fed FPBM or HFS diet. Pigs fed HML diet had higher standardized ileal digestibilities (SIDs) of DM and $\mathrm{CP}(\mathrm{p}<0.05$ and $\mathrm{p}<0.05$, respectively) compared to pigs fed the other FPBM and HFS diets. SIDs of total amino acid were not different $(p=0.06)$ between treatments. For SIDs of Lys, Met, and Thr, pigs fed HML and DMLM diets showed higher SIDs ( $p=0.05, p<0.05$, and $\mathrm{p}<0.05$, respectively) than pigs fed FPBM and HFS diets. SIDs of non-essential amino acids (aspartic acid, glycine, and alanine) were higher $(\mathrm{p}<0.05, \mathrm{p}<$ 0.05 , and $\mathrm{p}<0.05$, respectively) in pigs fed HML, FPBM, and DMLM diets than those in pigs fed the HFS diet. AID and SID of glutamic acid were higher in pigs fed HML and FPBM diets. Conclusion: In conclusion, dietary supplementation of mealworm larvae hydrolysate had higher digestibility in DM, CP, Lys, Met, and Thr compared to dietary supplementation with fermented poultry by-product and hydrolyzed fish soluble.

Keywords: Tenebrio Molitor; Mealworm Larvae Hydrolysate; Ileal Amino Acid Digestibility; Growing Pigs

\section{INTRODUCTION}

As the global population increase, there is a growing demand for meat production and the requirement of protein ingredients that are used to feed livestock also increase. However, traditional protein sources are no longer suitable to fully satisfy feed production growth in a sustainable way. Costs of soy meal and fish meal, environmental concerns, and diseases such as transmissible spongiform encephalopathy, foot and mouth disease, and avian influenza are drivers that lead to searches for alternative protein sources. The acceptance barrier 
may be lower for insects as food and feed. This is also reflected in the large number of trials on insects as sustainable proteinrich sources for aquaculture and livestock all over the world $[1,2]$, including trials on the common housefly (Musca domestica), the black soldier fly (Hermetia illucens), the yellow mealworm (Tenebrio molitor), locusts (Locusta migratoria, Schistocerca gregaria, Oxya spec., etc.), and silkworms (Bombyx mori). Insects emit considerably less greenhouse gas than most livestock, requiring smaller spaces and having high fecundity with fast-growth. In addition, insects are rich in proteins, energy, fats, minerals, and vitamins $[3,4]$. In general, proteins contents in insects are $40 \%$ to $65 \%$, similar to protein contents of fish meal, poultry meal, and meat meal $[1,3]$. However, insect proteins have higher utilization rates than proteins of these animal by-products [1]. Thus, insects are attracting attention as a substitute for fish meal, poultry meal, meat meal, and soybean meal $[1,3,5]$.

Among many insects, mealworm (Tenebrio molitor) larvae have attracted great attention. Dried mealworm larvae contain high amounts of crude protein (CP, $46 \%$ to $52 \%$ ) and fat (25\% to $35 \%$ ) which contains abundant essential fatty acids with superior oxidative stability $[1,6]$. Studies on the feed value of mealworm larvae for swine production have been done $[1,7,8]$. Results have indicated that dried mealworm larvae powder is a potentially promising protein source.

Feed ingredient processing includes heat treatment, fermentation, and enzymatic hydrolysis. These processes are used to increase the availability and reduce anti-nutritive factors of protein ingredients. In particular, hydrolysate contains a bioactive peptide having antimicrobial, antioxidant, and opioidlike effect. It has been focused as a strategy to optimize animal production because it contains short peptides and certain amino acids (AAs) (taurine, glycine [Gly], arginine, glutamic acid [Glu], and alanine [Ala]) that can enhance palatability. In addition, its small peptides can be readily absorbed in the small intestine. There have been several studies on nutritional values of fermented or hydrolyzed animal by-products to improve growth performance and nutrient digestibility [9-11]. Fermented fish meal was an effective protein ingredient to improve growth performance [9], and had higher apparent ileal digestibility of total AA than fish meal [11]. The hydrolyzed porcine intestinal mucosa product had similar to or greater degestible energy and metabolizable energy (ME) values than fish meal, and the standardized total track digestibility of phosphorus $(\mathrm{P})$ was greater than fish meal [10]. However, there is no research on the efficacy of mealworm larvae hydrolysate as feedstock. We hypothesize that the enzymatic hydrolysis process could improve digestibility and have positive effects on peptide and AA absorption by decreasing protein molecular weight of mealworm larvae. Therefore, the objective of this study was to investigate nutrient ileal digestibility of mealworm larvae hydrolysate in growing pigs compared to those of defatted mealworm larvae meal, fermented poultry by-product, and hydrolyzed fish soluble in growing pigs.

\section{MATERIALS AND METHODS}

\author{
Animal care \\ The experimental procedure was approved by the Institu- \\ tional Animal Care and Use Committee at Seoul National \\ University (SNU-191007-9).
}

\section{Experimental animal and design}

A total of 12 crossbred ([Landrace $\times$ Yorkshire $] \times$ Duroc) growing pigs with initial average body weight of $28.70 \pm 0.32 \mathrm{~kg}$ were surgically equipped with simple T-cannulas after they were deprived of feed for $24 \mathrm{~h}$ according to surgical procedures of Stein et al [12]. These pigs had a recovery period of two weeks. A total of 12 pigs were assigned to individual metabolic crates and allotted to one of four treatments (three replicates per treatment) in a fully randomized design. A total of 4 experimental diets were formulated using corn, soybean meal dextrin, palm kernel meal or wheat bran. Dietary treatments included the following: i) DMLM, the experimental diet which contained $10.0 \%$ defatted mealworm larvae meal (MPC, MILAE Bioresources Co., Ltd, Seoul, Korea); ii) HML, the experimental diet which contained $10 \%$ hydrolysate of mealworm (Tenebrio molitor) larvae; iii) FPBM, the experimental diet which contained $10 \%$ fermented poultry by-product (Neo-Pep, MOABIO Co., INC, Anyang, Korea); and iv) HFS, the experimental diet which contained $10 \%$ hydrolyzed fish soluble (FS Peptide, Sopropeche, Wimille, France). The defatted mealworm larvae meal, fermented poultry by-product, and hydrolyzed fish soluble are commonly available. They are used in the livestock feed industry. Chemical constituents of defatted mealworm larvae meal, hydrolysate of mealworm larvae, fermented poultry by-product and hydrolyzed fish soluble, and experimental diets are shown in Table 1 and 2.

\section{Preparation of hydrolysate}

The $40 \mathrm{~kg}$ of defatted mealworm meal (MPC, MILAE Bioresources Co., Ltd, Korea) was mixed in $360 \mathrm{~L}$ of water at room temperature. The $\mathrm{pH}$ was adjusted to $6.5-7.0$ using $1 \mathrm{~N} \mathrm{NaOH}$ before adding enzymes. No later adjustment of $\mathrm{pH}$ was made. Enzymes used were Alcalase 2.4 AU-A/g and Flavourzyme 500 LAPU/g (Novo Nordisk A/S, Bagsvaerd, Denmark). Dosages of Alcalase and Flavourzyme were $20 \mathrm{~mL}$ and $20 \mathrm{~g}$, respectively. Hydrolysis proceeded at $50^{\circ} \mathrm{C}$ for 3 hours with constant stirring at $40 \mathrm{rpm}$. Following hydrolysis, the hydrolyzed mixture was heated at $85^{\circ} \mathrm{C}$ for $30 \mathrm{~min}$ to inactivate enzymes followed by continuous centrifugation (MBPX810SGV-34CL, Alfa Laval, Lund, Sweden) at 9,000 rpm under $130 \mathrm{~L} / \mathrm{h}$ flow rate condition. After centrifugation, microbial cells were removed with a vibrating membrane separation process (Pollsep 
Table 1. Composition of defatted mealworm larvae meal, hydrolysate of mealworm larvae, fermented poultry by-product and hydrolyzed fish soluble, as-fed basis

\begin{tabular}{|c|c|c|c|c|}
\hline Chemical composition $^{1)}$ & $\begin{array}{l}\text { Defatted mealworm } \\
\text { larvae meal }^{2)}\end{array}$ & $\begin{array}{c}\text { Hydrolysate of } \\
\text { mealworm larvae }\end{array}$ & $\begin{array}{l}\text { Fermented poultry } \\
\text { by-product }{ }^{4)}\end{array}$ & Hydrolyzed fish soluble ${ }^{5)}$ \\
\hline Moisture (\%) & 8.50 & 10.58 & 5.83 & 5.38 \\
\hline Crude protein (\%) & 68.00 & 58.88 & 71.52 & 89.04 \\
\hline Crude fat (\%) & 4.00 & 0.26 & 11.22 & 7.00 \\
\hline Crude ash (\%) & 8.00 & 14.90 & 9.30 & 5.00 \\
\hline $\mathrm{Ca}(\%)$ & 0.60 & 0.20 & 0.10 & 0.20 \\
\hline Total phosporus (\%) & 0.50 & 0.82 & 1.00 & 0.75 \\
\hline \multicolumn{5}{|l|}{ Amino acid $^{6)}$} \\
\hline Essential & 36.76 & 30.05 & 31.44 & 19.24 \\
\hline Methionine & 2.07 & 3.02 & 1.96 & 1.36 \\
\hline Cystine & 0.87 & 0.75 & 0.67 & 0.15 \\
\hline Valine & 4.78 & 3.02 & 3.89 & 1.80 \\
\hline Isoleucine & 3.41 & 1.80 & 2.96 & 1.47 \\
\hline Leucine & 7.07 & 3.77 & 6.09 & 2.90 \\
\hline Phenylalanine & 3.74 & 2.07 & 3.44 & 1.76 \\
\hline Tyrosine & 3.41 & 1.15 & 2.92 & 0.00 \\
\hline Histidine & 1.49 & 0.92 & 2.89 & 1.52 \\
\hline Lysine & 5.82 & 10.36 & 3.12 & 6.00 \\
\hline Threonine & 4.10 & 3.19 & 3.50 & 2.28 \\
\hline Non-essential & 45.99 & 33.17 & 47.81 & 49.04 \\
\hline Serine & 6.18 & 3.19 & 3.80 & 3.89 \\
\hline Arginine & 6.01 & 3.19 & 5.86 & 4.93 \\
\hline Glutamic acid & 13.46 & 10.39 & 13.25 & 7.95 \\
\hline Aspartic acid & 7.66 & 4.82 & 7.54 & 5.33 \\
\hline Proline & 1.66 & 3.26 & 4.98 & 6.79 \\
\hline Glycine & 6.12 & 4.48 & 6.61 & 13.98 \\
\hline Alanine & 4.90 & 3.84 & 5.77 & 6.17 \\
\hline
\end{tabular}

1) Lab. of Daehanfeed Co. LTD.

2) Defatted mealworm (Tenebrio molitor) larvae meal: MPC, MILAE Bioresources Co., Ltd, Seoul, Korea.

${ }^{3)}$ Hydrolysate of mealworm (Tenebrio molitor) larvae.

${ }^{4)}$ Fermented poultry by-product: Neo-Pep, MOABIO Co., INC, Anyang, Korea.

${ }^{5)}$ Hydrolyzed fish soluble: FS Peptide, Sopropeche, Wimille, France.

6) $\mathrm{g} / 16 \mathrm{~g}$ nitrogen.

VMF 400, Poll, Port Washington, NY, USA). Following vibrating filtration, ultrafiltration was performed to obtain a hydrolysate having a molecular weight of $100 \mathrm{kDa}$ or less (ultrafiltration: MU-50000, Sartorius, Goettingen, Germany; filter model:Sartocon Cassette Hydrosart $100 \mathrm{kDa} 0.6 \mathrm{~m}^{2}$, Sartorius, Germany). To facilitate handling, the hydrolysate was mixed with malto-dextrin in a ratio of 1:1 and then dried in a freezing dryer.

Solubility and in-vitro digestibility

Nitrogen solubilities of hydrolysate of defatted mealworm larvae, defatted mealworm larvae meal, fermented poultry by-product, and hydrolyzed fish soluble were determined according to the method of Chobert et al [13]. Each $4 \mathrm{~g}$ of the sample mixed at 1:1 with dextrin was dispersed in $100 \mathrm{~mL}$ of distilled water followed by mixing with a Vortex for $10 \mathrm{~min}$. The $\mathrm{pH}$ was adjusted to 3 with $2 \mathrm{~N} \mathrm{HCl}$. The mixtures were centrifuged at a maximum speed of $3,400 \mathrm{rpm}$ (relative centrifugal force $=2,589 \mathrm{~g}$ ) for $10 \mathrm{~min}$ at room temperature (HA-300,
Hanil Industry Co, Deajeon, Korea). In-vitro CP digestibility was determined according to the method of Cho and Kim [14]. Nitrogen content of the supernatant was determined by using the Kjeldahl procedure with a Kjeltec (Kjeltec TM2200, Foss Tecator, Höganäs, Sweden) and CP content was then calculated (nitrogen $\times 6.25$; procedure 981.10 ; AOAC).

\section{Experimental diet and feeding}

The experimental diets were formulated to contain defatted mealworm larvae meal, hydrolysate of mealworm, fermented poultry by-product, or hydrolyzed fish soluble at level of $10.0 \%$. Chromic oxide was mixed to the diet at $0.5 \%$ as an indigestible marker to calculate digestibility. The calculated ME, CP, methionine (Met), lysine (Lys), calcium, and $\mathrm{P}$ requirement of experimental diets were adjusted according to requirements of NRC $[15,16]$ and kept same level among the test diets. Raw materials, chemical composition, AAs, and essential fatty acids compositions of experimental diets are shown in Table 2. Raw materials and chemical composition of nitrogen-free diets are 
Table 2. Composition of the experimental diets, as-fed basis

\begin{tabular}{|c|c|c|c|c|}
\hline \multirow{2}{*}{ Items } & \multicolumn{4}{|c|}{ Treatments $^{1)}$} \\
\hline & DMLM & HML & FPBM & HFS \\
\hline \multicolumn{5}{|l|}{ Ingredients (\%) } \\
\hline Ground corn & 65.01 & 54.81 & 62.54 & 67.44 \\
\hline Soybean meal, 45\% & 6.36 & 8.43 & 3.63 & 0.43 \\
\hline Defatted mealworm larvae meal & 10 & 0 & 0 & 0 \\
\hline Hydrolysate of mealworm larvae & 0 & 10 & 0 & 0 \\
\hline Fermented poultry by-product & 0 & 0 & 10 & 0 \\
\hline Hydrolyzed fish soluble & 0 & 0 & 0 & 10 \\
\hline Palm kernel meal & 4 & 10 & 4 & 0 \\
\hline Wheat bran & 0 & 0 & 5 & 7 \\
\hline Dextrin & 10 & 10 & 10 & 10 \\
\hline Tallow & 0.75 & 3.37 & 0.46 & 0.97 \\
\hline MDCP & 1.58 & 1.28 & 1.27 & 1.49 \\
\hline Limestone & 0.8 & 0.92 & 1.02 & 0.94 \\
\hline DL-methionine, 99\% & 0.05 & 0 & 0.14 & 0.1 \\
\hline L-threoninem 99\% & 0.09 & 0.19 & 0.29 & 0.26 \\
\hline L-lysine-HCl, 78\% & 0.36 & 0 & 0.65 & 0.37 \\
\hline Salt & 0.3 & 0.3 & 0.3 & 0.3 \\
\hline Vitamin premix ${ }^{2)}$ & 0.1 & 0.1 & 0.1 & 0.1 \\
\hline Mineral premix ${ }^{3)}$ & 0.1 & 0.1 & 0.1 & 0.1 \\
\hline $\mathrm{Cr}_{2} \mathrm{O}_{3}$ & 0.5 & 0.5 & 0.5 & 0.5 \\
\hline Sum & 100 & 100 & 100 & 100 \\
\hline \multicolumn{5}{|l|}{ (hemical composition ${ }^{4)}$} \\
\hline ME (kcal/kg) & 3,265 & 3,265 & 3,265 & 3,265 \\
\hline Crude protein (\%) & 15.69 & 15.69 & 15.69 & 15.69 \\
\hline Crude fat (\%) & 3.69 & 5.83 & 4.09 & 4.19 \\
\hline Crude fiber (\%) & 2.17 & 2.78 & 2.44 & 2.08 \\
\hline Lysine (\%) & 1.02 & 1.02 & 1.02 & 1.02 \\
\hline Methionine (\%) & 0.35 & 0.35 & 0.35 & 0.35 \\
\hline Threonine (\%) & 0.68 & 0.68 & 0.68 & 0.68 \\
\hline $\mathrm{Ca}(\%)$ & 0.66 & 0.66 & 0.66 & 0.66 \\
\hline Total P (\%) & 0.56 & 0.56 & 0.56 & 0.56 \\
\hline \multicolumn{5}{|l|}{ Essential fatty acid } \\
\hline Palmitic acid & 16.85 & 19.71 & 18.54 & 19.84 \\
\hline Stearic acid & 4.47 & 8.10 & 5.01 & 6.70 \\
\hline Oleic acid & 27.84 & 32.99 & 31.19 & 32.78 \\
\hline Linoleic acid & 39.34 & 24.49 & 35.55 & 36.66 \\
\hline Linolenic acid & 1.60 & 1.05 & 1.39 & 1.53 \\
\hline
\end{tabular}

MDCP, mono-di-calcium phosphate (Ca, $17.6 \%$ and total $P, 20.4 \%)$.

1) DMLM, the experimental diet which contained $10.0 \%$ defatted mealworm (Tenebrio molitor) larvae meal (MPC, MILAE Bioresources Co., Ltd, Seoul, Korea); HML, the experimental diet which contained 10\% hydrolysate of mealworm (Tenebrio molitor) larvae; FPBM, the experimental diet which contained 10\% fermented poultry by-product (NeoPep, MOABIO Co., INC, Anyang, Korea); and HFS, the experimental diet which contained 10\% hydrolyzed fish soluble (FS Peptide, Sopropeche, Wimille, France).

2) Provided the following per kilogram of diet: vitamin A, 12,000 IU as vitamin A acetate; vitamin $D_{3}, 2,000$ IU; vitamin $E, 40$ IU as dl-a-tocopheryl acetate; biotin, 0.3 mg as d-biotin; riboflavin, $5.0 \mathrm{mg}$; thiamine $3 \mathrm{mg}$ as thiamine mononitrate; pyridoxine $5 \mathrm{mg}$ as pyridoxine hydrochloride; folic acid $0.5 \mathrm{mg}$; pantothenic acid, $15 \mathrm{mg}$ as $\mathrm{d}$-calcium pantothenate; niacin, $30 \mathrm{mg}$ as nicotinic acid; vitamin $\mathrm{B}_{12}, 50 \mu \mathrm{g}$ as cyanocobalamin; and vitamin $\mathrm{K}_{3}, 2.0 \mathrm{mg}$ as menadione nicotinamide bisulfate.

3) Provided the following per kilogram of diet: $\mathrm{Cu} 15 \mathrm{mg}$ as $\mathrm{CuSO}_{4} \mathrm{H}_{2} \mathrm{O}$; Fe $120 \mathrm{mg}$ as $\mathrm{FeSO}_{4} \mathrm{H}_{2} \mathrm{O} ; \mathrm{Zn} 95 \mathrm{mg}$ as $\mathrm{ZnSO}_{4} \mathrm{H}_{2} \mathrm{O} ; \mathrm{Mn} 40 \mathrm{mg}$ as $\mathrm{MnSO}_{4} \mathrm{H}_{2} \mathrm{O} ; \mathrm{I}$ I.0 mg as $\mathrm{Ca}\left(\mathrm{IO}_{3}\right) \mathrm{H}_{2} \mathrm{O} ; \mathrm{Co} 0.5$ $\mathrm{mg}$ as $\mathrm{CoSO}_{4} \mathrm{H}_{2} \mathrm{O}$; and $\mathrm{Se} 0.3 \mathrm{mg}$ as $\mathrm{NaSeO}_{3} \mathrm{H}_{2} \mathrm{O}$.

4) Calculated values.

${ }^{5)}$ Measured values.

shown in Table 3. For $\mathrm{N}$-free diets, protein level was adjusted to the minimum with corn starch as base. Each pig was fed $1.15 \mathrm{~kg}$ of experimental diet two times a day at 07:00 and 19:00 h. Experimental diet provided 2.86 times of the maintenance energy requirement $\left(\mathrm{MEn}=106 \mathrm{kcal} \mathrm{ME} / \mathrm{kg}^{0.75}[15,16]\right)$. Water was available throughout the experimental period via a drinking nipple. 
Table 3. Composition of the nitrogen-free diets, as-fed basis

\begin{tabular}{lc}
\hline Items & \\
\hline Ingredient (\%) & 84.02 \\
Corn starch & 6.92 \\
Cellulose & 2.67 \\
MDCP & 0.39 \\
Limestone & 0.30 \\
Salt & 0.10 \\
Vitamin premix) & 0.10 \\
Mineral premix) & 0.50 \\
Cr $\mathrm{O}_{3}$ & 100.00 \\
Sum & \\
Chemical composition ${ }^{3)}$ & 3,265 \\
ME (kcal/kg) & 15.69 \\
Crude protein (\%) & 0.00 \\
Lysine (\%) & 0.00 \\
Methionine (\%) & 0.00 \\
Threonine (\%) & 0.66 \\
Ca (\%) & 0.56 \\
Total P (\%) & \\
\hline
\end{tabular}

MDCP, mono-di-calcium phosphate (Ca, 17.6\% and total $\mathrm{P}, 20.4 \%)$; ME, metabolizable energy.

1) Provided the following per kilogram of diet: vitamin $A, 12,000 \mathrm{IU}$ as vitamin $A$ acetate; vitamin $\mathrm{D}_{3}, 2,000 \mathrm{IU}$; vitamin $\mathrm{E}, 40 \mathrm{IU}$ as dl- $\alpha$-tocopheryl acetate; biotin, $0.3 \mathrm{mg}$ as d-biotin; riboflavin, $5 \mathrm{mg}$; thiamine $3 \mathrm{mg}$ as thiamine mononitrate; pyridoxine $5 \mathrm{mg}$ as pyridoxine hydrochloride; folic acid $0.5 \mathrm{mg}$; pantothenic acid, 15 $\mathrm{mg}$ as d-calcium pantothenate; niacin, $30 \mathrm{mg}$ as nicotinic acid; vitamin $\mathrm{B}_{12}, 50 \mu \mathrm{g}$ as cyanocobalamin; and vitamin $\mathrm{K}_{3}, 2.0 \mathrm{mg}$ as menadion nicotinamide bisulfate.

2) Provided the following per kilogram of diet: $\mathrm{Cu} 15 \mathrm{mg}$ as $\mathrm{CuSO}_{4} \mathrm{H}_{2} \mathrm{O}$; Fe 120 mg as $\mathrm{FeSO}_{4} \mathrm{H}_{2} \mathrm{O} ; \mathrm{Zn} 95 \mathrm{mg}$ as $\mathrm{ZnSO}_{4} \mathrm{H}_{2} \mathrm{O} ; \mathrm{Mn} 40 \mathrm{mg}$ as $\mathrm{MnSO}_{4} \mathrm{H}_{2} \mathrm{O} ; \mathrm{I} 1.0 \mathrm{mg}$ as $\mathrm{Ca}\left(\mathrm{IO}_{3}\right) \mathrm{H}_{2} \mathrm{O} ; \mathrm{Co} 0.5 \mathrm{mg}$ as $\mathrm{COSO}_{4} \mathrm{H}_{2} \mathrm{O}$; and $\mathrm{Se} 0.3 \mathrm{mg}$ as $\mathrm{NaSeO}_{3} \mathrm{H}_{2} \mathrm{O}$.

${ }^{3)}$ Calculated values.

\section{Sample collection}

Samples of ileal digested content were collected between 8:00 and 20:00 h for two days after five days of adaptation. Ileal digesta were collected into plastic bags attached to cannulas and emptied into plastic containers containing ice every 20 minutes. All samples were immediately transferred after sampling and stored in a $-20^{\circ} \mathrm{C}$ deep freezer to prevent changes in AAs sequence due to microbes until analysis. Samples were dried in a freezing dryer and finely ground to pass through a 1-mm screen for chemical analysis including moisture, CP, AAs, crude fat (Cfat), and fatty acids contents.

\section{Chemical analysis}

Diets and collected samples were grounded with a Cyclotec CT 193 Sample Mill (Foss Tecator, Hillerod, Denmark) and then analyzed. Analysis of dry matter (DM) was conducted according to AOAC Method 967.03. Nitrogen content was analyzed using the Kjeldahl procedure with a Kjeltec (Kjeltec TM2200, Foss Tecator, Sweden) and CP content was then calculated (nitrogen $\times 6.25$; procedure 981.10 ; AOAC). Cfat contents and fatty acid contents were analyzed according to Soxhlet method (AOAC Method 932.02) and BF3 methanol gas chromatography method (Trace GC, Thermo, Göteborg, EU; AOAC Method 940.28), respectively. For the analysis of AAs except for Met and cysteine, diets and samples were hydrolyzed in $6 \mathrm{~N} \mathrm{HCl}$ at $110^{\circ} \mathrm{C}$ for 24 hours (AOAC Method 999.13). The Met and cystine were determined after cold performic acid oxidation overnight and hydrolyzed with $7.5 \mathrm{~N}$ $\mathrm{HCl}$ (AOAC method 994.12). Individual AA was measured using an AA analyzer (Beckman 6300 Amino Acid Analyzer; Beckman Instruments Corp., Palo Alto, CA, USA). Chromium concentrations were determined using Inductively coupled plasma atomic emission spectroscopy (ICP-OES) (Thermo SCIENTIFIC, Waltham, MA, USA).

\section{Calculations}

Standardized ileal digestibilities (SIDs) of CP, Cfat, AAs, and fatty acids were calculated according to the method described by Stein $[17,18]$. Basal endogenous losses of CP and AAs were measured using samples collected at the end of the ileum after feeding with non-nitrogen feed. Calculation of digestibility was done based on relative chromium concentrations of feed and ileal samples. Apparent ileal digestibility (AID) and SID were calculated using the following equations:

$$
\begin{aligned}
& \text { AID }(\%)=100-[(\mathrm{ND} / \mathrm{NF}) \times(\mathrm{CrF} / \mathrm{CrD}) \times 100] \\
& \text { Basal endogenous AA losses }(\mathrm{EAL}, \mathrm{mg} / \mathrm{kg}) \\
& =[\mathrm{ND} \times(\mathrm{CrF} / \mathrm{CrD})] \\
& \mathrm{SID}(\%)=[\mathrm{AID}+(\mathrm{EAL} / \mathrm{NF})] \times 100
\end{aligned}
$$

Where ND (mg/kg), NF (mg/kg), CrF (mg/kg), and CrD $(\mathrm{mg} / \mathrm{kg})$ were nutrient concentration in the ileum digesta sample, nutrient concentration in the feed, chromium concentration in the feed, and chromium concentration in the ileum digesta sample, respectively.

\section{Statistical analysis}

The data for AID and SID of nutrients were statistically analyzed in a randomized complete block design using the general linear model procedure of SAS (SAS Inst. Inc., Cary, NC, USA). The model included dietary treatment as independent variable. Each pig was considered as the experimental unit. The differences among means were declared significant at $\mathrm{p}<0.01$ and $\mathrm{p}<0.05$. When the significance was declared, the fisher's least significance difference method was used to separate means. Variability in the data was expressed as standard error of means.

\section{RESULTS}

Nutrient contents of defatted mealworm larvae meal, mealworm larvae hydrolysate, fermented poultry by-product, and 
hydrolyzed fish soluble are summarized in Table 1 . These data indicated that defatted mealworm larvae meal had $36.76 \mathrm{~g} / 16 \mathrm{~g}$ nitrogen essential AAs, which was higher than other protein sources. The hydrolysate of mealworm larvae had the highest content (at $10.36 \mathrm{~g} / 16 \mathrm{~g}$ nitrogen) of Lys, an essential AA, followed by hydrolyzed fish soluble. The hydrolyzed mealworm larvae also had the highest content of Met+cystine (3.77 g/16 g nitrogen), followed by defatted mealworm larvae meal (2.94 $\mathrm{g} / 16 \mathrm{~g}$ nitrogen). Protein and ash contents of hydrolysate of mealworm larvae were $58.88 \%$ and $14.90 \%$, respectively. Results of nitrogen solubility and in-vitro digestibility analysis are shown in Table 4 . The solubility and digestibility of mealworm larvae hydrolysate were the highest $(85.71 \%$ and $98.96 \%$, respectively), followed by those of fermented poultry byproduct and hydrolyzed fish soluble. The nitrogen solubility and in-vitro digestibility of defatted mealworm larvae meal were the lowest (16.23\% and $50.11 \%$, respectively).

Results of AID are presented in Table 5. The AID of DM in pigs fed HML diet was the highest (89.47\%), which was significantly $(p<0.05)$ higher than those in pigs fed DMLM, FPBM, and HFS diets. AIDs of CP in pigs fed HML and DMLM diets were $89.31 \%$ and $86.37 \%$, respectively. They were significantly $(\mathrm{p}<0.05)$ higher than those in pigs fed FPBM and HFS diets. AID of total AA in pigs fed HML diet was 79.52\%, higher $(\mathrm{p}=0.06)$ than AIDs in pigs fed FPBM and DMLM diets. AIDs of Lys, Met, and threonine (Thr) were similar in pigs fed DMLM and HML diets. They were higher $(p=0.05$, $p<0.05$, and $p=0.05$, respectively) than those in pigs fed FPBM and HFS diets. There were no significant differences in AIDs of other essential AAs. AIDs of non-essential AAs (aspartic acid [Asp], Gly, and Ala) were higher ( $\mathrm{p}<0.05, \mathrm{p}<0.05$, and $\mathrm{p}<0.05$, respectively) in pigs fed HML, FPBM, and DMLM diets than in pigs fed HFS diet. In particular, AIDs of Glu, a palatability enhancer, in pigs fed HML and FPBM diets were $78.98 \%$ and $77.07 \%$, respectively. They were higher $(\mathrm{p}<0.05)$ than that in pigs fed the DMLM diet (72.71\%).

Compared to pigs fed FPBM and HFS diets, pigs fed HML diet had higher ( $p<0.05$ and $p<0.05$, respectively) SID of DM
(93.31\%) and CP (93.15\%) (Table 6). In comparison between HML and DMLM diets, pigs fed HML diet showed higher digestibility, although the difference between the two was not statistically significant. In the case of SIDs of total AAs, although there was no difference between treatments $(\mathrm{p}=0.06)$, pigs fed HML showed higher digestibility, followed by those fed with FPBM and DMLM diets. Regarding SIDs of Lys, Met, and Thr, pigs fed HML and DMLM diets showed higher SIDs ( $\mathrm{p}=0.05, \mathrm{p}<0.05$, and $\mathrm{p}<0.05$, respectively) than pigs fed FPBM and HFS diets. There were no significant differences in SIDs of other essential AAs. Same as the trend of AID, SIDs of non-essential AAs (Asp, Gly, and Ala) were higher $(\mathrm{p}<0.05, \mathrm{p}<0.05$, and $\mathrm{p}<0.05$, respectively) in pigs fed HML, FPBM, and DMLM diets than in pigs fed HFS diet. SIDs of Glu, a palatability enhancer, in pigs fed HML and FPBM diets were $82.82 \%$ and $80.91 \%$, higher $\mathrm{p}<0.05$ ) than that in pigs fed the DMLM diet. There were no significant differences in AID or SID digestibility of fatty acids except for those in pigs fed the DMLM diet.

\section{DISCUSSION}

Traditional protein sources used as feedstock have been proteins of animal or plant origin. However, interest in insect proteins as an alternative protein source that can be grown on organic streams has increased and the test have been conducted to compare insect proteins with several feed ingredients, such as fish meal, casein, spray-dried porcine plasma, soybean meal, and wheat gluten meal $[19,20]$. In the present experiment, we used hydrolysate of mealworm larvae, defatted mealworm larvae meal, and two processed animal by-products protein to compare their nutrient digestibilities in growing pigs.

In general, dried mealworm larvae contain high amounts of CP ( $46 \%$ to $52 \%)$ and fat (25\% to $35 \%)$ with relatively low ash content (3\% to $5 \%)[3,21,22]$. When dried mealworms are defatted through the degreasing process, $\mathrm{CP}$ content ranges from $65 \%$ to $70 \%$ [3,23-25]. In this experiment, $\mathrm{CP}$ and essential AA content in defatted mealworm larvae meal were

Table 4. Nitrogen solubility and in-vitro crude protein digestibility of defatted mealworm larvae meal, hydrolysate of mealworm larvae, fermented poultry by-product and hydrolyzed fish soluble

\begin{tabular}{|c|c|c|c|c|c|c|}
\hline Items & $\begin{array}{l}\text { Defatted mealworm } \\
\text { larvae meal }^{1)}\end{array}$ & $\begin{array}{c}\text { Hydrolysate of } \\
\text { mealworm larvae }\end{array}$ & $\begin{array}{l}\text { Fermented poultry } \\
\text { by-product }\end{array}$ & $\begin{array}{l}\text { Hydrolyzed fish } \\
\text { soluble }^{4)}\end{array}$ & SEM & p-value \\
\hline $2 \mathrm{~N} \mathrm{HCl}$ solubility ${ }^{5)}$ & $16.23^{d}$ & $85.71^{\mathrm{a}}$ & $68.82^{b}$ & $41.88^{c}$ & 0.39 & $<0.01$ \\
\hline In-vitro digestibility & $50.11^{d}$ & $98.96^{\mathrm{a}}$ & $93.77^{b}$ & $82.78^{c}$ & 0.28 & $<0.01$ \\
\hline
\end{tabular}

SEM, standard error of the mean.

1) Defatted mealworm (Tenebrio molitor) larvae meal: MPC, MILAE Bioresources Co., Ltd, Seoul, Korea.

${ }^{2)}$ Hydrolysate of mealworm (Tenebrio molitor) larvae.

3) Fermented poultry by-product: Neo-Pep, MOABIO Co., INC, Anyang, Korea.

4) Hydrolyzed fish soluble: FS Peptide, Sopropeche, Wimille, France.

5) Method described by Chorbert et al [18].

6) Method described by Cho and Kim [19].

a-d Means in a same row with different superscript are significantly different $(p<0.01)$. 
Table 5. Effect of protein ingredient on apparent ileal digestibility in growing pigs

\begin{tabular}{|c|c|c|c|c|c|c|}
\hline \multirow{2}{*}{ Items } & \multicolumn{4}{|c|}{ Treatments ${ }^{1)}$} & \multirow{2}{*}{ SEM } & \multirow{2}{*}{ p-value } \\
\hline & DMLM & HML & FPBM & HFS & & \\
\hline Dry matter (\%) & $87.45^{b}$ & $89.47^{\mathrm{a}}$ & $87.05^{b}$ & $85.88^{b}$ & 0.462 & $<0.01$ \\
\hline Crude protein (\%) & $86.37^{\mathrm{ab}}$ & $89.31^{\mathrm{a}}$ & $85.55^{b}$ & $83.41^{b}$ & 0.942 & 0.02 \\
\hline Crude fat (\%) & $82.12^{b}$ & $89.80^{\mathrm{a}}$ & $89.03^{\mathrm{a}}$ & $88.31^{\mathrm{a}}$ & 1.119 & $<0.01$ \\
\hline Total amino acid (\%) & 78.09 & 79.52 & 78.17 & 75.35 & 0.845 & 0.06 \\
\hline \multicolumn{7}{|c|}{ Essential amino acid (\%) } \\
\hline Lysine & $79.68^{\text {ab }}$ & $79.92^{\mathrm{a}}$ & $78.87^{b c}$ & $78.74^{c}$ & 0.269 & 0.05 \\
\hline Methionine & $79.78^{\mathrm{a}}$ & $79.93^{\mathrm{a}}$ & $79.17^{b}$ & $79.08^{b}$ & 0.160 & 0.02 \\
\hline Threonine & $79.36^{\mathrm{ab}}$ & $79.92^{\mathrm{a}}$ & $78.94^{b}$ & $78.83^{b}$ & 0.224 & 0.05 \\
\hline Valine & 76.76 & 78.26 & 78.87 & 69.69 & 2.261 & 0.09 \\
\hline Isoleucine & 76.45 & 78.02 & 78.98 & 72.62 & 1.658 & 0.13 \\
\hline Leucine & 77.17 & 78.27 & 78.88 & 75.81 & 1.017 & 0.25 \\
\hline Phenylalanine & 76.69 & 78.28 & 78.78 & 77.01 & 0.888 & 0.37 \\
\hline Histidine & 76.91 & 78.78 & 78.83 & 74.74 & 1.528 & 0.28 \\
\hline Arginine & 75.70 & 79.56 & 78.36 & 78.01 & 1.655 & 0.47 \\
\hline \multicolumn{7}{|c|}{ Non-essential amino acid (\%) } \\
\hline Aspartic acid & $74.83^{\mathrm{a}}$ & $78.36^{\mathrm{a}}$ & $77.74^{\mathrm{a}}$ & $68.06^{b}$ & 1.895 & 0.03 \\
\hline Serine & 74.99 & 78.55 & 79.01 & 67.85 & 2.774 & 0.09 \\
\hline Glutamic acid & $72.71^{\mathrm{bc}}$ & $78.98^{\mathrm{a}}$ & $77.07^{\mathrm{ab}}$ & $69.88^{c}$ & 1.319 & 0.01 \\
\hline Glycine & $65.32^{\mathrm{a}}$ & $76.83^{\mathrm{a}}$ & $76.35^{\mathrm{a}}$ & $39.53^{b}$ & 4.709 & $<0.01$ \\
\hline Alanine & $76.17^{\mathrm{a}}$ & $78.60^{\mathrm{a}}$ & $77.74^{\mathrm{a}}$ & $65.96^{b}$ & 1.385 & $<0.01$ \\
\hline Tyrosine & 74.70 & 77.44 & 78.54 & 77.58 & 1.350 & 0.31 \\
\hline Proline & 74.90 & 79.20 & 76.79 & 63.88 & 4.532 & 0.18 \\
\hline \multicolumn{7}{|l|}{ Fatty acid (\%) } \\
\hline Palmitic acid & $72.67^{b}$ & $79.74^{\mathrm{a}}$ & $79.05^{\mathrm{a}}$ & $79.67^{\mathrm{a}}$ & 0.928 & $<0.01$ \\
\hline Stearic acid & $72.35^{b}$ & $79.63^{\mathrm{a}}$ & $78.87^{\mathrm{a}}$ & $79.66^{\mathrm{a}}$ & 0.972 & $<0.01$ \\
\hline Oleic acid & $73.80^{b}$ & $79.89^{\mathrm{a}}$ & $79.39^{\mathrm{a}}$ & $79.93^{\mathrm{a}}$ & 0.915 & $<0.01$ \\
\hline Linoleic acid & $72.78^{b}$ & $79.83^{\mathrm{a}}$ & $79.13^{\mathrm{a}}$ & $79.51^{\mathrm{a}}$ & 1.120 & 0.01 \\
\hline Linolenic acid & $73.31^{b}$ & $79.81^{\mathrm{a}}$ & $78.76^{a}$ & $79.12^{\mathrm{a}}$ & 0.884 & $<0.01$ \\
\hline
\end{tabular}

SEM, standard error of means.

1) DMLM, the experimental diet which contained 10.0\% defatted mealworm (Tenebrio molitor) larvae meal (MPC, MILAE Bioresources Co., Ltd, Seoul, Korea); HML, the experimental diet which contained 10\% hydrolysate of mealworm (Tenebrio molitor) larvae; FPBM, the experimental diet which contained 10\% fermented poultry by-product (NeoPep, MOABIO Co., INC, Anyang, Korea); and HFS, the experimental diet which contained 10\% hydrolyzed fish soluble (FS Peptide, Sopropeche, Wimille, France).

${ }^{a-c}$ Means in a same row with different superscript are significantly different $(p<0.05)$.

$68 \%$ and 36.8 (g/16 g nitrogen) respectively, and the essential AA content was higher than those of other three proteins. The $\mathrm{CP}$ content was calculated by multiplying the nitrogen content by a factor of 6.5 , which was not an accurate method for insect proteins because mealworm larvae proteins were mainly composed of proteins derived from the exoskeleton, chiefly cuticular non-protein nitrogen known to contain chitin, a linear polymer of $\beta$-(1-4) $\mathrm{N}$-acetyl-D-glucosamine units with a chemical structure similar to that of cellulose $[20,26]$. When the CP content of mealworm larvae having exoskeleton was calculated using a factor of 6.25 , it could be overestimated by about $20 \%$. Therefore, a factor of 4.75 has been proposed for calculating the $\mathrm{CP}$ content of whole mealworm larvae having exoskeleton and a factor of 5.6 has been proposed for calculating aqueous extracted protein [27]. However, the defatted mealworm larvae meal used in this experiment was not only high in CP, but also high in essential AAs contents, which were comparable to those of other processed animal proteins. Contents of essential AAs Lys and Met+cystine in the defatted meal worm larvae meal were $5.82 \mathrm{~g}$ and $2.94 \mathrm{~g}$ per $16 \mathrm{~g}$ of nitrogen, respectively, similar to results of a previous study [26]. The CP content in mealworm larvae hydrolysate was $58.9 \%$. Although moisture content was corrected to $5 \%$, it was about $62.0 \%$, lower than those of other processed proteins used in this experiment and $74 \%$ of protein content obtained after the mealworm larvae was precipitated with acid $(\mathrm{pH}$ $=4$ ) and extracted with water [28]. In this experiment, ultrafiltration was performed to obtain a hydrolysate having a molecular weight of $100 \mathrm{kDa}$ or less. Relatively large molecular weight non-protein nitrogen might not be included in the hydrolysate. This was considered to be the reason why the $\mathrm{CP}$ content in the hydrolysate obtained in this experiment was low. Although CP and total essential AA contents in hydrolysate of mealworm were not higher than those in other 
Table 6. Effect of protein ingredient on standardized ileal digestibility in growing pigs

\begin{tabular}{|c|c|c|c|c|c|c|}
\hline \multirow{2}{*}{ Items } & \multicolumn{4}{|c|}{ Treatments $^{1)}$} & \multirow{2}{*}{ SEM } & \multirow{2}{*}{ p-value } \\
\hline & DMLM & HML & FPBM & HFS & & \\
\hline Dry matter (\%) & $91.29^{\mathrm{ab}}$ & $93.31^{\mathrm{a}}$ & $90.89^{b c}$ & $88.96^{c}$ & 0.462 & 0.02 \\
\hline Crude protein (\%) & $90.21^{\mathrm{ab}}$ & $93.15^{\mathrm{a}}$ & $89.39^{b}$ & $86.49^{b}$ & 1.081 & 0.04 \\
\hline Crude fat (\%) & $85.96^{b}$ & $93.64^{\mathrm{a}}$ & $92.87^{a}$ & $91.39^{\mathrm{a}}$ & 1.286 & 0.02 \\
\hline Total amino acid (\%) & 81.93 & 83.36 & 82.01 & 79.19 & 0.845 & 0.06 \\
\hline \multicolumn{7}{|c|}{ Essential amino acid (\%) } \\
\hline Lysine & $83.52^{\mathrm{ab}}$ & $83.76^{a}$ & $82.71^{b c}$ & $82.58^{\mathrm{c}}$ & 0.269 & 0.05 \\
\hline Methionine & $83.62^{\mathrm{a}}$ & $83.77^{\mathrm{a}}$ & $83.01^{b}$ & $82.92^{b}$ & 0.160 & 0.02 \\
\hline Threonine & $83.20^{\mathrm{ab}}$ & $83.76^{\mathrm{a}}$ & $82.78^{b c}$ & $82.67^{c}$ & 0.224 & 0.02 \\
\hline Valine & 80.60 & 82.10 & 82.71 & 73.53 & 2.261 & 0.09 \\
\hline Isoleucine & 80.29 & 81.86 & 82.82 & 76.46 & 1.658 & 0.13 \\
\hline Leucine & 81.01 & 82.11 & 82.72 & 79.65 & 1.017 & 0.25 \\
\hline Phenylalanine & 80.53 & 82.12 & 82.62 & 80.85 & 0.888 & 0.37 \\
\hline Histidine & 80.75 & 82.62 & 82.67 & 78.58 & 1.528 & 0.28 \\
\hline Arginine & 79.54 & 83.40 & 82.20 & 81.85 & 1.655 & 0.47 \\
\hline \multicolumn{7}{|c|}{ Non-essential amino acid (\%) } \\
\hline Aspartic acid & $78.67^{\mathrm{a}}$ & $82.20^{\mathrm{a}}$ & $81.58^{\mathrm{a}}$ & $71.90^{b}$ & 1.895 & 0.03 \\
\hline Serine & 78.83 & 82.39 & 82.85 & 71.69 & 2.774 & 0.09 \\
\hline Glutamic acid & $76.55^{\mathrm{bc}}$ & $82.82^{\mathrm{a}}$ & $80.91^{\mathrm{ab}}$ & $73.72^{c}$ & 1.319 & 0.01 \\
\hline Glycine & $69.16^{\mathrm{a}}$ & $80.67^{\mathrm{a}}$ & $80.19^{a}$ & $43.37^{b}$ & 4.709 & $<0.01$ \\
\hline Alanine & $80.01^{\mathrm{a}}$ & $82.44^{\mathrm{a}}$ & $81.58^{\mathrm{a}}$ & $69.80^{b}$ & 1.385 & $<0.01$ \\
\hline Tyrosine & 78.54 & 81.28 & 82.38 & 81.42 & 1.350 & 0.31 \\
\hline Proline & 78.74 & 83.04 & 80.63 & 67.72 & 4.532 & 0.18 \\
\hline \multicolumn{7}{|l|}{ Fatty acid (\%) } \\
\hline Palmitic acid & $76.71^{b}$ & $83.58^{\mathrm{a}}$ & $82.89^{a}$ & $81.72^{\mathrm{a}}$ & 1.097 & 0.01 \\
\hline Stearic acid & $76.19^{b}$ & $83.47^{\mathrm{a}}$ & $82.71^{a}$ & $81.72^{\mathrm{a}}$ & 1.051 & $<0.01$ \\
\hline Oleic acid & $77.64^{b}$ & $83.73^{\mathrm{a}}$ & $83.23^{\mathrm{a}}$ & $81.99^{\mathrm{a}}$ & 1.114 & 0.03 \\
\hline Linoleic acid & $76.62^{b}$ & $83.67^{\mathrm{a}}$ & $82.97^{\mathrm{a}}$ & $81.56^{\mathrm{a}}$ & 1.311 & 0.03 \\
\hline Linolenic acid & $77.15^{c}$ & $84.41^{\mathrm{a}}$ & $82.60^{\mathrm{ab}}$ & $79.89^{b c}$ & 0.875 & $<0.01$ \\
\hline
\end{tabular}

SEM, standard error of means.

1) DMLM, the experimental diet which contained 10.0\% defatted mealworm (Tenebrio molitor) larvae meal (MPC, MILAE Bioresources Co., Ltd, Seoul, Korea); HML, the experimental diet which contained 10\% hydrolysate of mealworm (Tenebrio molitor) larvae; FPBM, the experimental diet which contained 10\% fermented poultry by-product (NeoPep, MOABIO Co., INC, Anyang, Korea); and HFS, the experimental diet which contained 10\% hydrolyzed fish soluble (FS Peptide, Sopropeche, Wimille, France).

a-c Means in a same row with different superscript are significantly different $(p<0.05)$.

processed animal proteins, Lys and Met+cystine contents were the highest (10.4 $\mathrm{g}$ and $3.8 \mathrm{~g}$ per $16 \mathrm{~g}$ nitrogen, respectively) in the hydrolysate of mealworm. Values of essential AA (Lys, Met+cysteine, and Thr) index (EAAI) [29] for defatted mealworm larvae meal, hydrolyzed mealworm larvae, fermented poultry by-product, and hydrolyzed fish soluble were $0.51,0.49,0.40$, and 0.44 , respectively (AA requirements based on Daehan Feed Co. data). EAAI values of defatted mealworm larvae and hydrolyzed mealworm larvae were similar to each other, but higher than those of fermented poultry by-product and hydrolyzed fish soluble. The ash content of mealworm larvae hydrolysate was higher than those (from about $4.0 \%$ to $12.0 \%$ ) of hydrolysate of poultry viscera (8.8\%), fish protein concentrates (6.0\%) and isolates (4.0\%), fermented fish silage (4.6\%) and hydrolyzed porcine intestinal mucosa product (10.0\% and $12.0 \%)$ [10,30-32]. There was no process to increase ash content in enzymatic hydro- lysis. However, the ash content was higher than that of the feed ingredient (defatted mealworm meal, $8 \%$ ) used for hydrolysis in the present study. The ash content of the raw material has a great effect on energy evaluation. Thus, it should be reconfirmed in future studies in terms of feed ingredient value.

Digestibility was measured when experimental diets containing $25 \%$ to $35 \%$ plant-derived protein ingredients were fed to pigs ranging from $18 \mathrm{~kg}$ to $59 \mathrm{~kg}$ body weight [33-35]. The CP AID of diets including Chinese, Argentine, and Korean soybean meal were $70.34 \%, 71.30 \%$, and $76.57 \%$ respectively, while that of diet including rapeseed meal was $66.34 \%$ in pigs with body weight of $58.6 \mathrm{~kg}$ [33]. The CP, Lys, and Met SID of diet including soybean meal were $84.03 \%, 85.02 \%$, and $87.27 \%$, respectively, in pigs with body weight of $18.2 \mathrm{~kg}$ [34]. AID of CP, Lys, and Met of diet including canola meal were $62.0 \%, 72.0 \%$, and $77.4 \%$, respectively, in pigs with body weight 
of $35.0 \mathrm{~kg}$ [35]. The CP AID and SID of DMLM, HML, FPBM, and HFS diets were similar to or higher than those of diets including plant protein ingredients, such as soybean meal, rapeseed meal and canola meal. Based on reviews and the result that AID and SID of experimental diets were equal to or higher than those of diets including several plant protein ingredients, it can be inferred that digestibilities of the defatted mealworm larvae meal, hydrolysate of mealworm, hydrolyzed poultry by-product, and fermented fish soluble used in this experiment could be generally higher than those of plant protein ingredients. Jin et al [36] have shown that the total track digestibilities of CP were $92.17 \%$ and $93.04 \%$ in pigs fed diets including $4.5 \%$ and $6.0 \%$ dried mealworm larvae, respectively. Although they [36] measured total digestibility in younger pigs than those of our study, the result showed higher digestibility than AID (86.37\%) and SID (90.21\%) in the present study due to differences in experimental diet composition and lower feeding amount ( $2 \%$ of body weight) in their study than that of this study ( $4 \%$ of body weight). Defatted mealworm larvae meal had the lowest solubility in 2 $\mathrm{N} \mathrm{HCl}$ solution and in-vitro digestibility, however CP AID and SID in pigs fed DMLM diet were similar to those in pigs fed FPBM and HFS diets. It could be said that the digestibility of the DMLM diet was not negatively affected by the defatted mealworm larvae meal at 10\% usage level.

Insect proteins may also have increased availability when processed. Although there are studies on the physiological activity of low molecular weight mealworm larvae peptide in the field of food [22,26], few studies have evaluated mealworm larvae peptide as a protein source in pig nutrition when processed. In comparison between HML and DMLM diets, DM AID of HML diet was $89.47 \%$, higher than that of DMLM diet (87.45\%). AIDs of CP and total AA and SIDs of DM, CP, and total AA tended to be higher in HML diet than those in DMLM diet, although there was no statistically significant difference between the two diets. The lower nitrogen solubility in $2 \mathrm{~N} \mathrm{HCl}$ solution and CP digestibility of DMLM diet might have attributed to indigestibility of chitin- $\mathrm{N}$ and/or acid detergent fiber bound-N. Chitin, a linear polymer of $\beta-(1-4) \mathrm{N}-$ acetyl-D-glucosamine units with a chemical structure similar to that of cellulose, is combined with protein and distributed widely on shell of crabs, shrimp and insects. It is soluble in a narrow range of $\mathrm{HCl}$, carboxylic and sulfonic acids, namely, formic, di- and trichloroacetic and methanesulfonic acids and slowly degraded. It is distributed in the form of chitin-protein complexes as a major component of the cuticle layer of mealworm larvae $[20,26]$. When proteins are hydrolyzed to low molecular weight peptides, they can be easily absorbed into the body with high utilization rates. Solubility and in-vitro digestibility of hydrolysate of defatted mealworm larvae meal were $85.71 \%$ and $98.96 \%$, respectively, higher than those of defatted mealworm (Tenebrio molitor) larvae meal, fermented poultry by-product and hydrolyzed fish soluble. The higher solubility and digestibility suggested extensive hydrolysis of mealworm larvae into short peptides, which were more soluble compare to intact and the other two processed animal protein sources. We used a combination of Alcalase (endopeptidase) and Flavourzyme (exo-peptidase) which have similar optimum activity temperature and $\mathrm{pH}$ conditions [37]. When mealworm larvae protein was hydrolyzed using Alcalase and Flavourzyme, it was hydrolyzed to less than 100 $\mathrm{kDa}$ [22]. Hydrolyzed low molecular weight peptides could be rmore eadily absorbed than raw mealworm protein. Although only proteins having a molecular weight of $100 \mathrm{kDa}$ or less were measured, the recovery rate was $13.8 \%$ (data not shown), higher than that (9.97\%) in experiment using enzymatic hydrolyzed poultry meal [37]. However, this recovery rate was lower than that in other study [22] using hydrolyzed mealworm larvae protein. It takes about 6 to 8 hours for mealworms to be fully hydrolyzed using Alcalase and Flavorzyme [22]. However, in the present study, hydrolysis was performed for only 3 hours in consideration of industrial economics, so the recovery rate was low.

In pigs fed the HML diet, since the hydrolysate of mealworm larvae was composed only of peptides with molecular weight of $100 \mathrm{kDa}$ or less, AID and SID of DM and CP were higher than those of FPBM and HFS diets. In another study [38], the CP AID of hydrolysed fish soluble was $87.0 \%$, higher than results of the present study. AID and SID of test diets including mealworm larvae-derived ingredients were higher than those of FPBM and HFS diets. This meant that the digestibility of mealworm protein was high regardless of processing. Thus, it had a relatively high value as a protein ingredient. The quality of hydrolysed fish soluble may vary depending on the composition, type, and fish species of raw materials used for hydrolysis. However, hydrolysate of mealworm larvae may have less variation in quality because it used relatively less varied mealworm larvae meal.

Results of this study showed that hydrolyzed mealworm (Tenebrio molitor) larvae would be a suitable ingredient in growing pigs. It is especially valuable from the stand-point of $\mathrm{CP}$ and essential AA ileal digestibility. In younger pigs, hydrolysate of mealworm larvae could replace fermented poultry by-product and hydrolyzed fish soluble. High CP and essential AA ileal digestibility of mealworm larvae hydrolysate containing diet may act on the deposition of AAs in pig meat and the growth performance of growing pigs. Further studies are needed to explore this possibility. In addition, research in the area of mealworm larvae hydrolysate may lead to discovery of novel peptide sequences that might be more potent and/or more bioavailable than bioactive peptides generated from more conventional dietary proteins. 


\section{CONCLUSION}

In conclusion, dietary supplementation of mealworm larvae hydrolysate had higher digestibility in DM, CP, Lys, Met, and Thr compared to dietary supplementation with fermented poultry by-product and hydrolyzed fish soluble. The nitrogen soulubility and in-vitro CP digestibility of mealworm larvae hydrolysate were also high. Thus, mealworm larvae hydrolysate can be a potentially attractive alternative protein-rich feed ingredient in growing pigs.

\section{CONFLICT OF INTEREST}

We certify that there is no conflict of interest with any financial organization regarding the material discussed in the manuscript. Cho KH, Yoo JS are employees of Daehan feed Co., Ltd., and Kwon GT is an employee of Berry \& Biofood Research Institute.

\section{ACKNOWLEDGMENTS}

This work was supported by Korea Institute of Planning and Evaluation for Technology in Food, Agriculture, Forestry and Fisheries (IPET) through Technology Commercialization Support Program funded by Ministry of Agriculture, Food and Rural Affairs (MAFRA) (Project No.:817025-03).

\section{REFERENCES}

1. Yoo JS, Cho KH, Hong JS, et al. Nutrient ileal digestibility evaluation of dried mealworm (Tenebrio molitor) larvae compared to three animal protein by-products in growing pigs. Asian-Australas J Anim Sci 2019;32:387-94. https://doi.org/ 10.5713/ajas.18.0647

2. Laura G, Ilaria B, Sihem D, Achille S, Francesco G. Animals fed insect-based diets: State-of-the-Art on digestibility, performance and product quality. Animals 2019;9:170. https:// doi.org/10.3390/ani9040170

3. Makkar HPS, Tran G, Heuze V, Ankers P. State-of-the-art on use of insects as animal feed. Anim Feed Sci Technol 2014; 197:1-33. https://doi.org/10.1016/j.anifeedsci.2014.07.008

4. Berg J, Wendin K, Langton M, Josell A, Davidsson F. State of the Art Report: Insects as food and feed. Ann Exp Biol 2017; 5:37-46.

5. Stamer A. Insect proteins-a new source for animal feed: The use of insect larvae to recycle food waste in high-quality protein for livestock and aquaculture feeds is held back largely owing to regulatory hurdles. EMBO Rep 2015;16:676-80. https://doi.org/10.15252/embr.201540528

6. Ravzanaadii N, Kim SH, Choi WH, Hong JS, Kim NJ. Nutritional value of mealworm, Tenebrio molitor as food source. Int J Indust Entomol 2012;25:93-8. https://doi.org/10.7852/ ijie.2012.25.1.093

7. Jin XH, Heo PS, Hong JS, et al. Supplementation of dried mealworm (Tenebrio molitor larva) on growth performance, nutrient digestibility and blood profiles in weaning pigs. Asian-Australas J Anim Sci 2016;29:979-86. https://doi.org/10.5713/ajas.15. 0535

8. Ji YJ, Liu NH, Kong XF, et al. Use of insect powder as a source of dietary protein in early-weaned piglets. J Anim Sci 2016; 94(Suppl 3):111-6. https://doi.org/10.2527/jas.2015-9555

9. Lee HJ, Choi IH, Kim DH, et al. Influence of fermented fish meal supplementation on growth performance, blood metabolites, and fecal microflora of weaning pigs. R Bras Zootec 2017;46:433-7. http://dx.doi.org/10.1590/s1806-92902017000 500010

10.Sulabo RC, Mathai JK, Usry JL, et al. Nutritional value of dried fermentation biomass, hydrolyzed porcine intestinal mucosa products, and fish meal fed to weanling pigs. J Anim Sci 2013; 91:2802-11. https://doi.org/10.2527/jas.2012-5327

11. Cho JH, Kim IH. Effects of fermented fish meal on $\mathrm{N}$ balance and apparent total tract and ileal amino acid digestibility in weanling pigs. J Anim Vet Adv 2011;10:1455-9. https://doi. org/10.3923/javaa.2011.1455.1459

12.Stein HH, Shipley CF, Easter RA. Technical note: a technique for inserting a T-cannula into the distal ileum of pregnant sows. J Anim Sci 1998;76:1433-6. https://doi.org/10.2527/1998. $7651433 \mathrm{x}$

13. Chobert JM, Sitohy MZ, Whitaker JR. Solubility and emulsifying properties of caseins modified enzymatically by Staphylococcus aureus V8 Protease. J Agric Food Chem 1988;36:2204. https://doi.org/10.1021/jf00079a055

14. Cho JH, Kim IH. Evaluation of the apparent ileal digestibility (AID) of protein and amino acids in nursery diets by in vitro and in vivo methods. Asian-Australas J Anim Sci 2011;24: 1007-10.

15.NRC. Nutrient requirements of swine (10th Ed.). Washington, DC, USA: National Academy Press; 1998.

16.NRC. Nutrient requirements of swine (11th Ed.). Washington, DC, USA: National Academy Press; 2012.

17.Stein HH, Aref S, Easter RA. Comparative protein and amino acid digestibilities in growing pigs and sows. J Anim Sci 1999; 77:1169-79. https://doi.org/10.2527/1999.7751169x

18.Stein HH, Kim SW, Nielsen TT, Easter RA. Standardized ileal protein and amino acid digestibility by growing pigs and sows. J Anim Sci 2001;79:2113-22. https://doi.org/10.2527/2001. 7982113x

19.van Huis A. Potential of insects as food and feed in assuring food security. Annu Rev Entomol 2013;58:563-83. https://doi. org/10.1146/annurev-ento-120811-153704

20.Kar SK, Jansman AJM, Boeren S, Kruijt L, Smits MA. Protein, peptide, amino acid composition, and potential functional properties of existing and novel dietary protein sources for monogastrics. J Anim Sci 2016;94(Suppl 3):30-9. https://doi. 
org/10.2527/jas.2015-9677

21.Siemianowska E, Kosewska A, Aljewicz M, et al. Larvae of mealworm (Tenebrio molitor L.) as european novel food. Agric Sci 2013;4:287-91. https://dx.doi.org/10.4236/as.2013.46041

22. Yu MH, Lee HS, Cho HR, Lee SO. Enzymatic preparation and antioxidant activities of protein hydrolysates from Tenebrio molitor larvae (Mealworm). J Korean Soc Food Sci Nutr 2017; 46:435-41. https://doi.org/10.3746/jkfn.2017.46.4.435

23. Ravzanaadii N, Kim SH, Choi WH, et al. Nutritional value of mealworm, Tenebrio molitor as food source. Int J Indust Entomol 2012;25:93-8. https://doi.org/10.7852/ijie.2012.25. 1.093

24. Kouřimská L, Adámková A. Nutritional and sensory quality of edible insects. NFS J 2016;4:22-6. https://doi.org/10.1016/ j.nfs.2016.07.001

25.Zielińska E, Baraniak B, Karaś M, et al. Selected species of edible insects as a source of nutrient composition. Food Res Int 2015;77:460-6. https://doi.org/10.1016/j.foodres.2015.09. 008

26. Yi L, Lakemond CMM, Sagis LMC, Eisner-Schadler V, van Huis A, van Boekel MA. Extraction and characterisation of protein fractions from five insect species. Food Chem 2013; 141:3341-8. https://doi.org/10.1016/j.foodchem.2013.05.115

27. Janssen RH, Vincken JP, van den Broek LAM, et al. Nitrogento-protein conversion factors for three edible insects: Tenebrio molitor, Alphitobius diaperinus, and Hermetia illucens. J Agric Food Chem 2017;65:2275-8. https://doi.org/10.1021/acs.jafc. $7 \mathrm{~b} 00471$

28. Yi L, Van Boekel M, Lakemond CMM. Extracting Tenebrio molitor protein while preventing browning: effect of $\mathrm{pH}$ and $\mathrm{NaCl}$ on protein yield. J Insects Food Feed 2017;3:21-31. https:// doi.org/10.3920/JIFF2016.0015

29. Smith DM. Protein separation and characterization procedures. In: Nielsen SS, editor. Food analysis. Chapter 15. New York, NY, USA: Springer Verlag; 2010. pp. 263-80.
30. Jamdar SN, Harikumar P. A rapid autolytic method for the preparation of protein hydrolysate from poultry viscera. Bioresour Technol 2008;99:6934-40.

31. Koeleman E. Peptones: A welcome new ingredient for animal feed. Feed Tech 2008;12:15-7.

32. Panda S, Babu LK, Panda AK, Tanuja S, Panigrahy K. Dietary supplementation of fermented fish silage in broiler japanese quails (Coturnix coturnix japonica) - a review. Int J Livest Res 2017;7:31-48. https://x.doi.org/10.5455/ijlr.20170306091640

33. Han YK, Kim IH, Hong JW, et al. Apparent ileal digestibility of nutrient in plant protein feedstuffs for finishing pigs. AsianAustralas J Anim Sci 2003;16:1020-4. https://doi.org/10.5713/ ajas.2003.1020

34. Zhang HY, Yi JQ, Piao XS, et al. The metabolizable energy value, standardized ileal digestibility of amino acids in soybean meal, soy protein concentrate and fermented soybean meal, and the application of these products in early-weaned piglets. Asian-Australas J Anim Sci 2013;26:691-9. https://doi.org/10. 5713/ajas.2012.12429

35. Adebiyi AO, Ragland D, Adeola O, Olukosi OA. Apparent or standardized ileal digestibility of amino acids of diets containing different protein feedstuffs fed at two crude protein levels for growing pigs. Asian-Australas J Anim Sci 2015;28:1327-34. https://doi.org/10.5713/ajas.14.0914

36. Jin XH, Heo PS, Hong JS, Kim NJ, Kim YY. Supplementation of dried mealworm (Tenebrio molitor larva) on growth performance, nutrient digestibility and blood profiles in weaning pigs. Asian-Australas J Anim Sci 2016;29:979-86. https://doi. org/10.5713/ajas.15.0535

37. Nchienzia HA, Morawicki RO, Gadang VP. Enzymatic hydrolysis of poultry meal with endo- and exopeptidases. Poult Sci 2010;89:2273-80. https://doi.org/10.3382/ps.2008-00558

38. Kofavet Co. LTD. New lighting of peptide nutrition and application of fish peptides. Technical Bulletin; 2016;4:1-9. 